Abstracta Iranica Abstracta Iranica

Revue bibliographique pour le domaine irano-aryen

Volume 25 | 2004

Comptes rendus des publications de 2002

\title{
Prominent Tajik Figures of the Twentieth Century. Douchanbeh, The International Borbad Foundation, 2002, 436 p., index.
}

\section{Stéphane A. Dudoignon}

\section{(2) OpenEdition}

1 Journals

\section{Édition électronique}

URL : http://journals.openedition.org/abstractairanica/5086

DOI : 10.4000/abstractairanica.5086

ISSN : 1961-960X

Éditeur :

CNRS (UMR 7528 Mondes iraniens et indiens), Éditions de l'IFRI

\section{Édition imprimée}

Date de publication : 15 mai 2004

ISSN : 0240-8910

Référence électronique

Stéphane A. Dudoignon, « Prominent Tajik Figures of the Twentieth Century. Douchanbeh, The International Borbad Foundation, 2002, 436 p., index. », Abstracta Iranica [En ligne], Volume 25 | 2004, document 295, mis en ligne le 15 mars 2006, consulté le 25 septembre 2020. URL : http://

journals.openedition.org/abstractairanica/5086 ; DOI : https://doi.org/10.4000/abstractairanica.5086

Ce document a été généré automatiquement le 25 septembre 2020.

Tous droits réservés 


\title{
Prominent Tajik Figures of the
} Twentieth Century. Douchanbeh, The International Borbad Foundation, 2002, 436 p., index.

\author{
Stéphane A. Dudoignon
}

L'A. (biographie p.417) est un linguiste iranien émigré aux États-Unis, reconverti depuis une dizaine d'années dans les études historiques générales sur l'Asie Centrale. Son ouvrage, utile même aux chercheurs maîtrisant le tadjik et le russe, dresse une sorte d'autoportrait des élites politiques et culturelles du Tadjikistan - dominées dans ce répertoire par les écrivains, critiques littéraires et chercheurs en sciences humaines. Une lecture à compléter, sur l'abondant réseau, aujourd'hui défonctionnarisé, de l'Union des Écrivains du Tadjikistan, par celle de l'ouvrage ci-dessous.

INDEX

Thèmes : 11.3. Littérature Asie centrale

\section{AUTEURS}

STÉPHANE A. DUDOIGNON

Université Marc Bloch - Strasbourg 